Document downloaded from:

http://hdl.handle.net/10251/73080

This paper must be cited as:

Pérez-Esteve, Ė; Bernardos Bau, A.; Martínez-Máñez, R.; Barat Baviera, JM. (2013). Nanotechnology in the Development of Novel Functional Foods or their Package. An Overview Based in Patent Analysis. Recent Patents on Food, Nutrition and Agriculture. 5(1):35-43. http://hdl.handle.net/10251/73080.

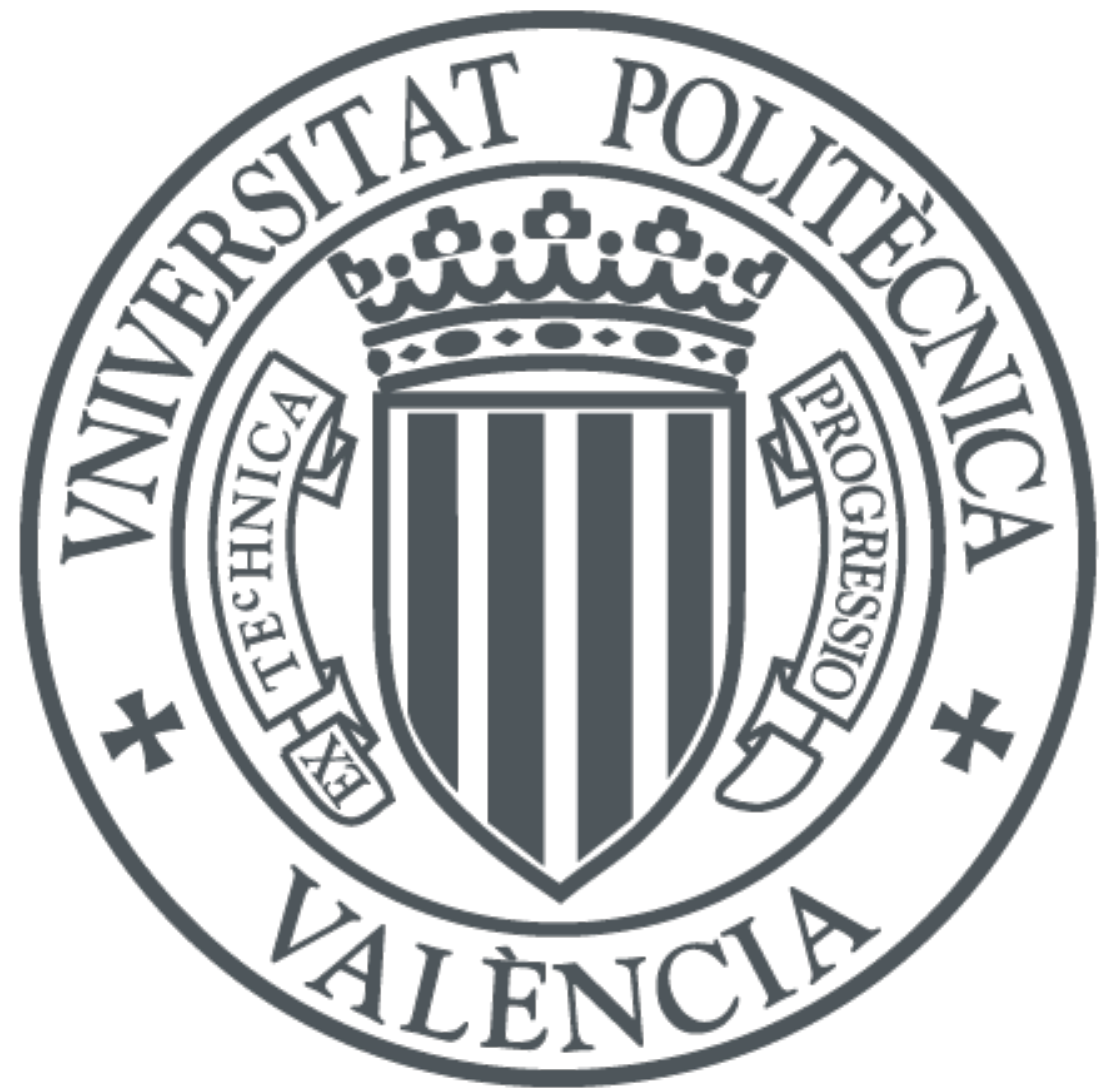

The final publication is available at

http://www.ingentaconnect.com/contentone/ben/pfna/2013/00000005/00000001/art00006

Copyright Bentham Science Publishers

Additional Information 


\title{
Nanotechnology in the development of Novel Functional Foods or their Package. An overview based in patent analysis
}

\author{
Edgar Pérez-Esteve ${ }^{1}$, Andrea Bernardos ${ }^{1,2}$, Ramón Martínez-Máñez $^{2,3}$, José M. Barat $^{1^{*}}$
}

1. Grupo de Investigación e Innovación Alimentaria, Departamento de Tecnología de Alimentos, Universidad Politécnica de Valencia, Camino de Vera s/n, Valencia, 46022, Spain

2. Centro de Reconocimiento Molecular y Desarrollo Tecnológico (IDM), Unidad Mixta Universidad Politécnica de Valencia - Universidad de Valencia. Departamento de Química Universidad Politécnica de Valencia, Camino de Vera s/n, 46022, Valencia, Spain

\section{CIBER de Bioingeniería, Biomateriales y Nanomedicina (CIBER-BBN)}

*Address correspondence to this author at the Departamento de Tecnología de Alimentos, Universidad Politécnica de Valencia, C/ Camino de Vera s/n, 46022, Valencia, 46022, Spain.

Tel: +34 963877365, Fax +34 963879369; E-mail: jmbarat@ tal.upv.es; Alternative E-mail: rmaez@qim.upv.es, edpees@upv.es, anberba@upv.es

\section{Short Running Title: Nanotechnology patents in the development of Novel Functional Foods or their Package.}

\begin{abstract}
In recent years nanotechnology has become a significant component in food industry being present in all food chain steps, from the design of new ingredients or additives to the most modern systems of food quality methods or packaging, demonstrating the great potential of this new technology in a sector as traditional as food. However, while the industry's interest in nanotechnology increases, the rejection by consumers concerned about the potential risk does too. Thus, is this worry affecting the use and development of nanotechnology applications in the food sector? The aim of this review is to evaluate the development rate of food nanotechnology by means of patents analysis, highlight current applications of nanotechnology along the whole food chain and contextualizing this evolution in social scene.
\end{abstract}

Key words: additive, antimicrobial agents, food control, immobilized enzymes, nanosensors, nanotechnology, novel food, packaging.

\section{INTRODUCTION}

XXI century is witnessing a new scientific and industrial revolution coming from the hand of the manipulation of matter at the nanometric level, also known as nanotechnology. This emerging discipline referred to the techniques for designing, fabricating, measuring and manipulating matter at the nanometre scale, grows at a dizzying pace.

Nanomaterials exhibit different chemical and physical properties, such as size, size distribution, surface area, surface properties, shape, chemical composition and agglomeration state that are not apparent in bulk materials. Hence, it is not surprising that applications of nanotechnology in several fields of industry, such as cosmetics, medicine, food, construction materials, etc. have grown tremendously in the last decade.

The budget increase of the American National Nanotechnology Initiative (NNI) from approximately \$464 million in 2001 to nearly $\$ 2.1$ billion for the 2012 [1] is an irrefutable sign of this growth. Also, it is expected that the overall impact of the nanotechnology market will reach one trillion U.S. dollars by 2015, housing about 2 million workers [2]. 
The advance of nanotechnology could also been explained by the analysis of the number of patents. Figure 1, shows the number of patents of the last 20 years, for each of the 13 nanotechnology families defined by Ludlow et al, 2007 [3]. As observed, all different families have experienced an increase in the last 5 years, signifying that nanotechnology with independency of the field, is an area in expansion. In this growth, 2011 has been an important year with more than 10.000 new patents related with development of nanotechnology process and applications.

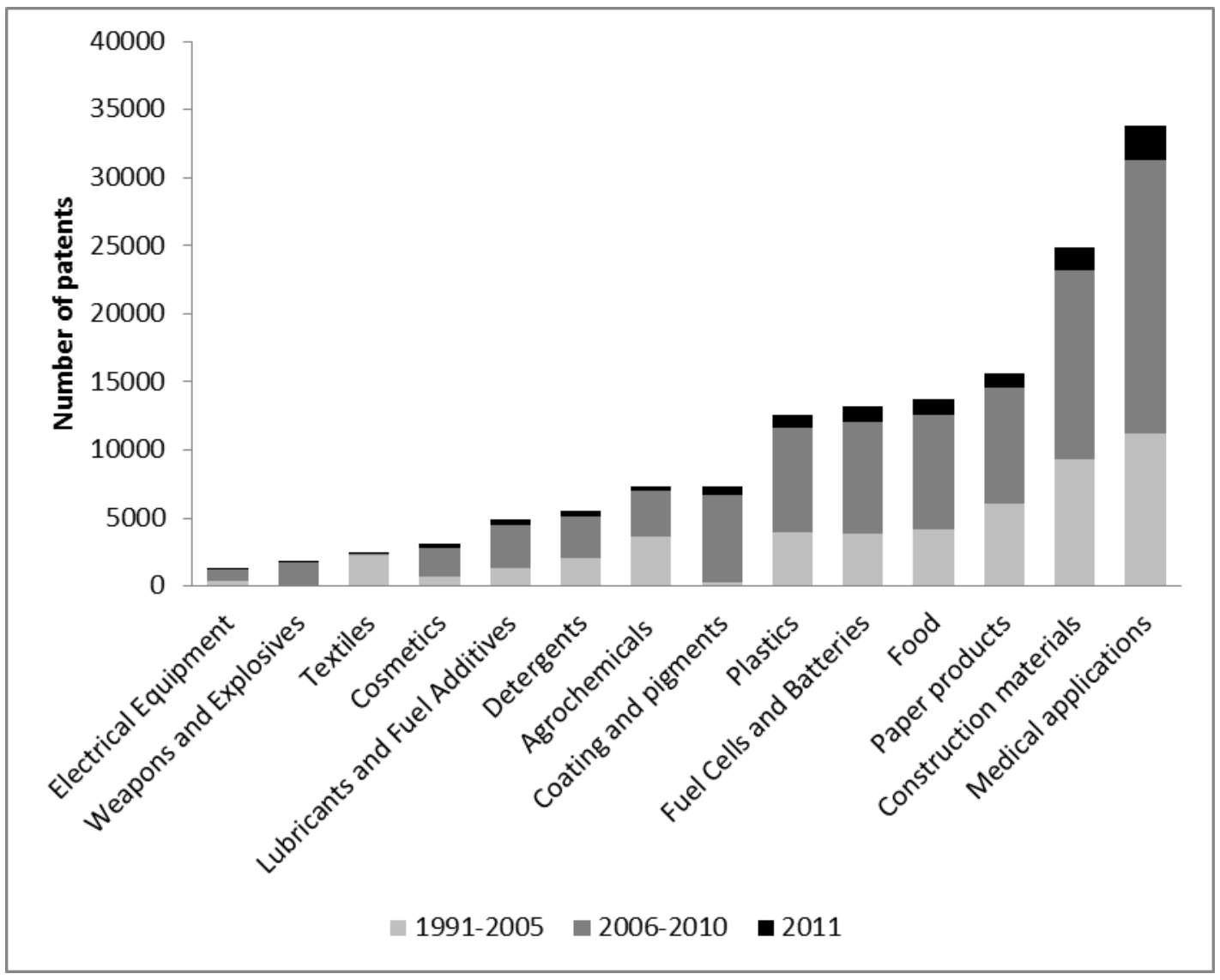

Fig. (1). Number of Nanotechnology-Related Patents filed in the last 20 years classified according Ludlow's Nanotechnology Families.

The fact that nanoparticles have high surface/volume ratio, re-assembling and self-reassembling capability, are held in suspension by Brownian motion, have the ability to create porous structures and could be used in the production of optimized materials compatible with typical polymers used in food packaging or edible films or coatings [4], makes them of great potential in a number of industries, including food.

Nanoscale can be used in food technology to modify the structure and quality of foodstuffs improving taste, flavor, color, texture, and consistency of foodstuffs. Also is employed to get better absorption and bioavailability of nutraceuticals and health supplements, via reducing their size or via encapsulation, to develop food antimicrobials or new food packaging materials with improved mechanical barriers and antimicrobial properties and to manufacture new nanosensors for traceability and monitoring the condition of food during transport and storage [5].

This tantalizing potential of nanotechnology has seduced by the moment more than 400 companies around the world, including Kraft, Nestle, Unilever, Keystone, Heinz, Hershey, etc. [6] and this number is expected to grow in coming years. This fact states that nanotechnology is quickly moving from the 
laboratory onto supermarket shelves and our kitchen tables and has the potential to revolutionize food systems [7]. Unilever, for instance, has made ice cream healthier without compromising on taste through the application of nanoemulsions; Nestle, has patented a water-in-oil emulsion (10-500nm) aiming at achieving quicker and simpler thawing through the addition of polysorbates and other micelle-forming substances [2].

The use of nanotechnology in food has the potential to revolutionize food process, food features and also the way in which foods arrive to our hands, once packaged and evaluated. Nanotechnology is also expected to provide new novel foods, defined as a type of food that does not have a significant history of consumption or which is produced by a method that has not previously been used for food.

However, with these potential benefits could come potential risks, due to the use of novel materials in novel ways. Nanoparticle properties are not governed by the same laws as larger particles, having different physical and chemical properties such as colour, solubility, chemical reactivity, and toxicity [8]. Thus, the extensive use of nanoparticles in foods may not be growing as it should be expected in the near future because of possible safety or environmental concerns. In a study carried out by Martin et al, 2012, is shown how there are part of the population that have developed a kind of food technology neophobia, in which nanotechnology is immersed [9]. This could explain not only the opposition to use nanotechnology in food packaging and food applications but also opposition to the use of nanotechnology in general, even if it could solve environmental or health problems.

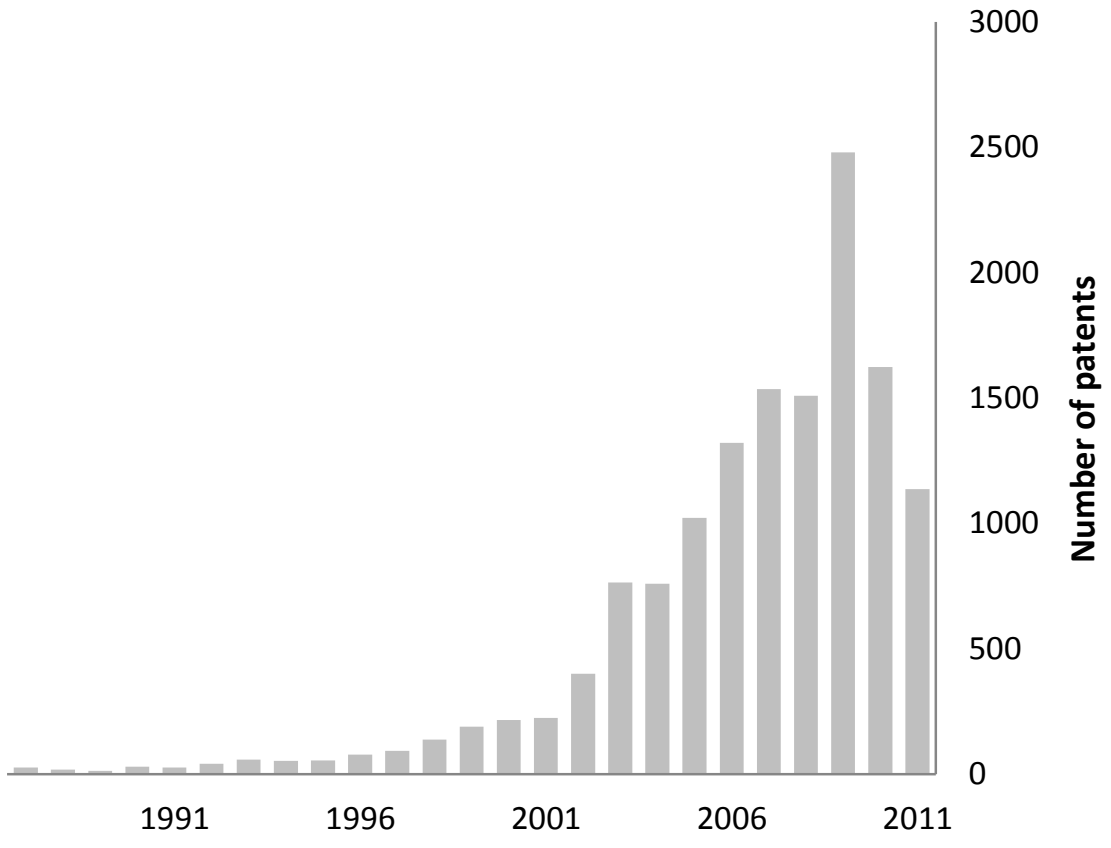

Fig (2). Evolution of the number of patents in Nanotechnology related with the Food Processing and Production family filed in the last 25 years.

This social phobia or fear to the nanosize could explain how despite nanotechnology potential, since 2009 the number of patents related with the food industry has not grown with lately tendency (Fig. 2). However, it has to be taken into account that nanosize is also presented in common foods. In fact, food being "the of Nature's own nanotechnology" is not a new concept for nanoscience [6]. For instance, food proteins as native beta-lactoglobulin have a size about $3.6 \mathrm{~nm}$, and via denaturalization are capable to reassemble forming larger structures, such as fibrils or aggregates, which can be assembled to form even larger gel networks[10]. The result of these molecular assembly processes could be considered to be a product of nanotechnology, or simply be called yogurt. 
Thus, the fear of the unknown should not back away the development and research. Of course, the entry of new products that have not been evaluated to the markets should not be allowed, whether nanotechnology has been used or not. This is the challenge of regulatory governmental agencies, in whose hands lies with regulations as (EC) No 450/2009, in which active and intelligent materials and articles intended to come into contact with food are regulated [11]. In this context new nanotechnologies which have been already discovered or remain yet to be explored, if managed and regulated correctly, could play a central role in improving food features, production, processing, packaging, and safety.

In this review, we discuss recent patents related to nanotechnology and nanomaterials used in food industry. This patent's analysis provides valuable information that could be useful in the identification of trends at the commercialization of nanotechnology and to identify new gaps of research.

\section{NANOTECHNOLY IN THE FOOD INDUSTRY. WHERE COULD IT BEEN FOUND?}

At the beginning, nanotechnology and nanocomposites used in food industry were only related with nanofiltration membranes. Now, 20 years later and according to this review, nano-applications can be found in each of the steps of the production chain, from the designing of the ingredients, to the packaging and the wrapping up of the final product. In the present review, results of the patents found in the SCIRUS database by using the key word "Nano Food", have been filtered and classified according to the application in the food processing and production chain, obtaining five categories or approaches Fig.(3).

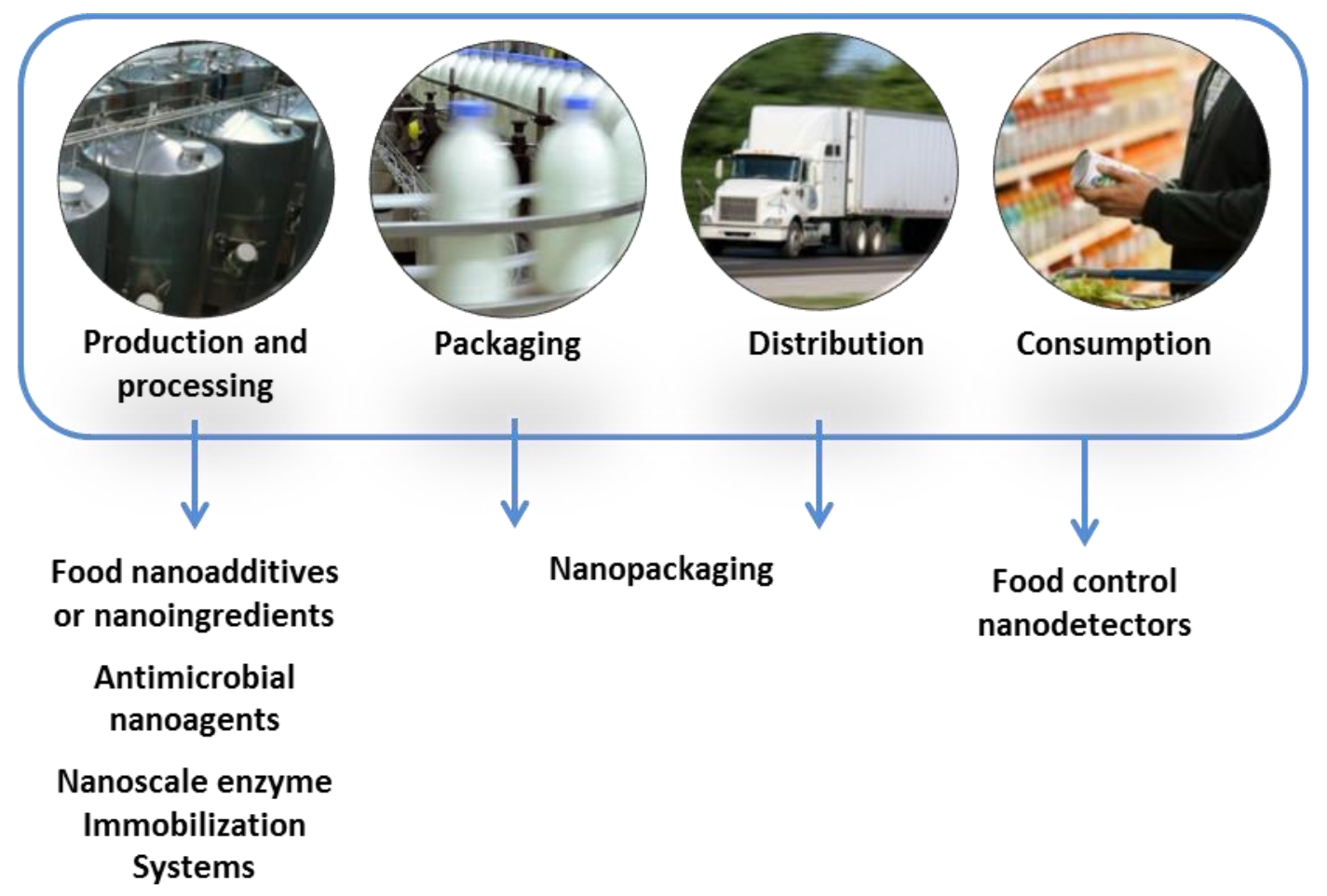

Fig. (3). Five categories of nanotechnology applications according to the steps in food chain

\section{FOOD PRODUCTION AND PROCESSING}

\section{Food nanoadditives and nanoingredients}

Food industries are one of the most innovative due to the need of look for products with added value that enable them to compete on the market and increase the benefits. The application of nanotechnology, due 
to its capability to modify physicochemical properties from those at natural scale, can allow modification of many macroscale characteristics of food, such as texture, taste, other sensory attributes, coloring, strength, processability, water solubility, stability during shelf life, thermal stability, and oral bioavailability of functional compounds [2].

During last decade, a number of bioactive molecules have attracted the attention of consumers due to their in-vitro demonstrated activity as antioxidants, anticancer, or preventing chronic diseases. However, the same effect has not always been demonstrated in in-vivo applications, probably due to their low stability or their poor solubility. In consequence, development of stable dietary supplements with good bioavailability and protection of valuable nutrients against degradation during manufacturing and storage, are some goals of food technology to ensure the attributed benefits that can be achieved by using nanotechnology. For instance, nanoparticulated nutrients such as selenium nanospheres with high purity and homogeneous particle-size distribution [12], nano-particles containing calcium which show an excellent absorption rate [13] and nanocristals of lycopene and resveratrol [14] have opened new strategies for absorption and bioavailability of nutrients and functional compounds in the body. Nanoemulsions have also received a great attention due to their ability to solubilizing lipophilic molecules, e.g. coenzyme Q10, an oil-soluble vitamin-like substance, improving its stability and bioavailability [15].

The change of size and shape can also benefit the industry of food additives providing new features. For example, titanium dioxide $\left(\mathrm{TiO}_{2}\right)$ or E-171, an authorized colour additive which produces nontransparent white film as microsize crystals, exhibits high visual transparency with high shielding against UV light when it is used as nanometric particles [16].

In the field of delivery systems for food applications, nanotechnology has also provided new strategies to encapsulate nutrients, bioactive compounds, additives, and also probiotics. Casein [17] and beta-casein micelles [18] are excellent systems as nano-encapsulators for hydrophobic additives, providing not only an increased solubility in aqueous environments, but also exceptional stability to temperature and within a wide $\mathrm{pH}$ range. Nanoparticles of zein, a class of prolamine protein found in maize, have also been patented to encapsulate water-soluble or liposoluble biologically active compounds [19]. Other examples of nanotechnology involve the use of colloidally stable dispersions of nanoparticles containing $\beta$ lactoglobulin and polysaccharides [20] which are transparent when diluted in aqueous media. Lipid-based nano-delivery systems such as liposomes to encapsulate proteins [21], archaeosomes to encapsulate Coenzyme-Q and vitamin E [22] or nanocochleates to encapsulate fragile nutrients, e.g., beta carotene [23], have been also proposed as a good trial to protect bioactive molecules from the media. In general, colloidal stable dispersions of nanoparticles have proved useful as delivery vehicles of hydrophobic nutraceuticals and fat-soluble vitamins for enrichment of food products, especially of transparent beverages and other non-fat or low fat foods and drinks. Engineered nanomaterials such as carbon nanotubes [24] or mesoporous silica materials [25], have also been proposed as drug sustained-release agents for oral administration.

Nanoencapsulation of probiotics as a tool to achieve longer survival during passage through the human gastro-intestinal tract and during the processing and storage of functional food products has also been patented [26].

Hence, different nanostructures such as nanoemulsions, nanocristals, nanoparticles or nanoencapsulators, are capable to offer the sector of food additives and ingredients paths to obtain new properties and overall, to increase preservation of active ingredients in the digestive system or during production and storage, improving nutrients and nutraceuticals bioaccessibility and bioavailability.

\section{Antimicrobial nanoagents}

Nanoparticles have also been patented as antimicrobial agents. Examples of favourable nanoparticles used as antimicrobial products include the use of nanoparticulated silver, gold, zinc, copper, cerium [27], 
aluminum, iron, cadmium, palladium, rhodium or chrome [28]. Nanometals agents act by releasing metal ions that react with proteins in the microorganism rendering the protein insoluble and thereby inactive. The inactive protein perturbs cellular function, disrupts membranes and prevents the normal activity and reproduction of DNA thereby essentially killing the microorganism [27].

Of all, silver has proved to be the most effective having numerous advantages over other antimicrobial agents, and its effect can also be increased by the combination with other antimicrobial substances such as extracts of grapefruit, purslane, or with essential oils [29], having the mixtures excellent antimicrobial activity.

Compared to molecular antimicrobials, which are generally targeted to specific organism classes, silver shows a broad spectrum and is toxic (to varying degrees) to numerous strains of bacteria, fungi, algae, and possibly some viruses. Nanosilver is highly reactive, as it binds to tissue proteins and brings structural changes in the bacterial cell wall and nuclear membrane leading to cell distortion and death. Silver also binds to bacterial DNA and RNA by denaturing and inhibits bacterial replication [30].

Particularly, in the case of colloidal silver solutions, having silver dispersed in the state of nanoparticles, silver is able to suffocate and kill virus, bacteria, mold and fungi by penetrating into the germ cells and stopping the function of enzymes required for respiration [31].

Due to these properties, nanosilver has been included in formulations of detergents used for washing food, cookers, tableware, food processing devices, food cooking machines, etc. [32]. Silver nanoparticles have also been used as sterilizer of freeze-dried food by an associated sterilization method comprising ozone, ultraviolet and nano-silver [33] and employed in formulations of antimicrobial films [34].

Besides its use as an antimicrobial agent, silver nanoparticles can also act as anti-ripening agents in the agricultural industry. Malse et al, 2007, have patented a method based on silver-coated nano/micro particles placed in the camera where fruits are stored to enable the conversion of the ethylene generated by fruits, which is the phytohormone responsible for fruit ripening, to ethylene oxide, which not only lacks of the hormonal activity but also destroy biological species such as fungi, bacteria and spores [35].

\section{Nanoscale enzyme immobilization systems}

For food industries, improving and shorting times are as important as obtain new food additives, ingredients or antimicrobial agents in food production and processing. Accordingly, use of enzymes is a practice fully extended in food industry. Specificity of enzyme catalysts promise improvements in many applications, such as sugar and corn syrups, dairy, baking products, alcohol drinks, meat tenderness or cheese ripening, but the short lifetime of enzymes presently limit their usefulness. To solve this problem, one important approach to improve their efficiency consists of using immobilized enzyme systems. This can reduce the required amount of enzymes, prolong the lifetime of enzyme reactors, increase the potential for enzyme reuse, and maintain a good signal when using biosensors [36].

Scientific literature widely describes the advantages of using enzyme immobilization for their use in industry. There are several works focused in the study of the improvement of enzyme activity, stability and selectivity [37,38], techniques for enzyme immobilization including covalent binding, ionic and hydrophobic adsorption, aggregation and entrapment [39] and efforts addressed towards controlling the orientation of the enzyme on the immobilization support [40]. However, a poor biocatalytic efficiency of immobilized enzymes, often limits the development of large-scale bioprocessing to compete with traditional chemical processes [41].

Thus, some authors conclude that selection of proper immobilization supports should be done and new supports need to be prepared to improve the efficiency of immobilization and orientation processes [37, 40]. In this sense, nanostructures such as spheres, fibres and tubes provide an ideal alternative to the 
usually issues encountered in the optimization of immobilized enzymes: minimum diffusional limitation, maximum surface area per unit mass, and high enzyme loading [36].

Despite all these advances in science, very few patents are available at the moment. However, there is enough information to study which nanoparticles are the most commonly used as support and conclude that silica and nanoporous silica materials have been the most extensively used in enzyme immobilization. The importance of the use of porous silica relies on their unique features, such us the stability and biocompatibility, the capability to avoid mechanisms of inactivation, the fact than they can be prepared with tailor-made pores, show very large specific surface areas involving therefore large load capacity and have a well-known and relatively easy functionalisation chemistry that can lead to a control of both size and pore polarity. Hence, porous silica supports can be prepared with various sizes, shapes and functionalities [42] to host several kinds of enzymes as it is shown in table 1.

In the same line, carbon nanotubes have been used for the immobilization of high concentrations of enzymes. For instance, carbon nanotubes have been used in electrode applications, leading to an improvement of the sensitivity and the response speed [45]. $\mathrm{ZnO}$ [46] and gold nanopaticles [47] have also been used as nanoplatforms for enzyme immobilization.

Table 1. Summary of Patents Aimed to develop nanoscaled enzyme immobilization systems

\begin{tabular}{|l|l|l|l|l|}
\hline Enzyme & $\begin{array}{l}\text { Immobilization } \\
\text { nanoplatform }\end{array}$ & Objective & Patent number & Ref. \\
\hline $\begin{array}{l}\text { Amylase, } \\
\text { glucoamylase, } \\
\text { cellulase, xylanase, } \\
\text { glucoseisomerase }\end{array}$ & $\begin{array}{l}\text { Zeolites and } \\
\text { silica gel }\end{array}$ & $\begin{array}{l}\text { Increase activity and stability for the use } \\
\text { in industrial processes. }\end{array}$ & WO2004081208 & 43 \\
\hline $\begin{array}{l}\text { Hydrolases, } \\
\text { perhydrolases, } \\
\text { haloperoxidases }\end{array}$ & $\begin{array}{l}\text { Silica-based } \\
\text { nanomaterial or } \\
\text { carbon } \\
\text { nanotubes }\end{array}$ & $\begin{array}{l}\text { Produce oxygen metabolites at } \\
\text { concentrations sufficient to kill or } \\
\text { inactivate a variety of different infectious } \\
\text { agents. }\end{array}$ & WO2010123534 & 44 \\
\hline Thermolysin & Silica gel & $\begin{array}{l}\text { Produce low molecular weight protamine } \\
\text { (LMWP). }\end{array}$ & WO2007050100 & 42 \\
\hline
\end{tabular}

\section{PACKAGING AND DISTRIBUTION}

\section{Food Nanopackaging}

Packaging is likely the sector where nanotechnology is becoming more present. The huge possibilities of nanotechnology to influence packaging are reflected in the more than $\$ 7$ billion that are projected by 2014 for the nano-derived packaging for food and beverages [48]. Also, these figures could increase more when the use of nanotechnology to improve packaging materials will not be as costly as it is nowadays. Thus, attending the possibilities of the nanopackaging and the necessity of improve the process to produce them, it is not surprising that this sector represents the major percentage of published patents.

Perhaps the most promising application in food packaging is the use or nanocomposites or polymeric matrices comprising reinforcements of less than $100 \mathrm{~nm}$ in size. These nanoscale fillers such as carbon nanotubes [49], cellulose [50], oxides [51] and clays [52] in composite films represent a radical, favorable alternative to conventional polymer composites due to their capability of making packages more flexible, strong, versatile, and also biodegradable. Moreover, polymers manufactured at the nanoscale are able to offer new properties such as controlled porous size.

Due to this versatility, nanocomposites with target barrier properties have been widely designed and applied for the conservation of vegetables and fruits, controlling residual oxygen [53,54, 55, 56], water vapor [57] or the accumulation of ethylene generated by fresh fruits and vegetables [58]. Nanocomposites 
are also able to protect meat products from the oxidation [59] or aqueous drinks from water vapor lost [60]. But, not only chemical barriers can be obtained by using nanocomposites. But also films containing nano-sized particles of inorganic oxides exhibit strong UVa and UVb absorption features [61]. Moreover polymers contain nanoscalar zinc oxide in their composition, have been reported to produce polyolefin films with UV-barrier properties conserving the transparence [50]. Examples of nanoparticles used in these applications are shown in table 2 .

Research in nanocomposites, not only looks for the improvement of packaging properties but also for environmental protection. In this line, nanoclays used in combination with renewable materials such as starch [64, 65] soy protein [66], lactic acid [67] and chitosan [68] are becoming an important alternative to traditional packaging materials. These bionanocomposites, made from biodegradable materials, not only have the potential to protect the food and increase its shelf life but can also be considered more environmentally friendly via the reduction of the requirement to use plastics as packaging materials [69].

Another research area involves the use of nanotechnology in order to enhance product attributes, such as colour by using thermoplastic webs containing a myoglobin blooming agent that fix a desirable colour on the surface of the product [70], and flavour by minimizing the influence of gases or vapours and light permeating from the outside of the packaging container [71].

The use of nanoscale fillers in composite films can also extend the shelf-life of products via the use of "active packaging" and "smart packaging", either acting as antimicrobial agents or as a sensors. Nanocomposites can be equipped with an antimicrobial activity, being a new way to control surface microbial contamination of food. In this line, the use of silver-containing nanomaterials has been described to mitigate growth of microorganisms, including fungi $[72,73]$. Also, packaging is able to respond actively to certain changes in the product itself or changes in the package environment, e.g. polymers containing chromogenic particles that change their color after a contact with an analyte [74] acting as a nanosensors.

Table 2. Summary of Patents Aimed to develop Active Packaging

\begin{tabular}{|c|c|c|}
\hline $\begin{array}{l}\text { Nano-size } \\
\text { particle }\end{array}$ & Brief Description & Ref \\
\hline Alumina & $\begin{array}{l}\text { Polymer with dispersed alumina particles having enhanced oxygen transfer } \\
\text { barrier properties. }\end{array}$ & 56 \\
\hline Calciumsilicate & $\begin{array}{l}\text { Calcium silicate nanostructures to absorb ethylene and carbon dioxide emitted } \\
\text { during fruit ripening. }\end{array}$ & 57 \\
\hline $\begin{array}{l}\text { Hemicellulose }+ \\
\text { plasticizers }\end{array}$ & Polymeric nanocomposited film acting as an oxygen, aroma or grease barrier. & 53 \\
\hline $\begin{array}{l}\text { Low density } \\
\text { polyethylene }+ \\
\text { olefin polymer }\end{array}$ & $\begin{array}{l}\text { Film having a carbon dioxide scavenger for vacuum packaging of meat } \\
\text { products. }\end{array}$ & 62 \\
\hline Polyester + Clays & $\begin{array}{l}\text { Polyester resins with dispersed scavenging for packaging oxygen sensitive } \\
\text { food. }\end{array}$ & 54 \\
\hline $\begin{array}{l}\text { Polyethylene } \\
\text { fabric }\end{array}$ & $\begin{array}{l}\text { Nano perforated film to maintain a predetermined gas composition in } \\
\text { modified or controlled atmosphere packaging. }\end{array}$ & 63 \\
\hline $\begin{array}{l}\text { Starch } \\
\text { nanocrystals }\end{array}$ & Multi-layer film with oxygen barrier and scavenging layer properties. & 55 \\
\hline Silica & $\begin{array}{l}\text { Paper with nano structured silicates in the form of platelets used in controlled } \\
\text { environment packaging. }\end{array}$ & 49 \\
\hline $\begin{array}{l}\text { Silica }+ \\
\text { magnesium } \\
\text { silicate }\end{array}$ & Biodegradable nano-polymer compositions comprising mineral nanoparticles. & 61 \\
\hline
\end{tabular}




\section{FOOD CONTROL PROCESSES}

\section{Food control nanodetectors}

Finally, in each of these stages of the food chain (production, processing, packaging, distribution and also consumption), health authorities and consumers want to ensure food security. Every day we have access to more and more different food and those, due to globalization, can come from very different places. Therefore, it is not surprising that foodborne illnesses are yet the reason of a big number of poisonings and deaths every year [75].

To minimize the potential health and economic impacts of foodborne pathogens, contaminants such as veterinary drugs, pesticides, phytotoxins and marinetoxins chemicals created during processing techniques and in spoiled food, it is necessary to use rapid, selective, reliable and specific detections methods. However, conventional methods such as spectrophotometry and chromatography, PCR, culture and colony counting, immunological techniques or fluorescence based assays using organic dye molecules, require skilled personnel and are time consuming, laborious and expensive. Also, they do not always produce accurate results, especially when the analyses are performed rapidly and cost-cutting is paramount [76].

In this context, the development of new techniques for a sensitive detection of food toxicants, pathogens or spoilage products using nanotechnology are being developed as a novel strategy for monitoring food safety in all food chain steps.

Nanosensors using single particles, such as carbon nanotubes, or arrays of nanoparticles, such as quantum dots, have been used. Carbon nanotubes have been considered due to their small size, high strength, high electrical and thermal conductivity, and high specific area. They have found applications as sensors in several fields including agriculture, food industry and environmental monitoring [77]. For instance, use of carbon nanotube's conductance change provoked by the presence of target analytes, such as pesticides, toxins, or contaminants, has been patented to detect these species in solution, eliminating the need for immobilizing the analyte on a support [78]. Quantum dots, meanwhile, are fluorescent semiconductor nanoparticles with narrow, very specific and stable emission spectra constructed from elements of Groups II-VI, III-V and IV-VI of the periodic table [79]. Quantum dots-based sensor arrays have been reported for differentiating the strain of a variety of biological molecules including bacteria, spores, fungi, viruses, and disease-causing prions [80].

Another approach includes the use of nanomaterials in the fabrication of electrochemical or optical sensors. For instance, Lei and Ding, 2012, have patented a non-enzymatic glucose sensors based on an electrode built with metal oxide nanofibers [81]. Ferrao et at, 2007, patented a photosensor for food quality control based in quantify colour variations produced by gold nanoparticles functionalized by oligonucleotides and other ligands complementary to specific DNA/RNA sequences or proteins [82].

In a third approach are included devices based on the concept of biosensing. A biosensor is a device formed by two parts: a biological component that interacts specifically with its target, and a transducer, which measures the signal change provoked by the biological component, which is proportional to the target concentration. In this approach, carbon nanotubes have also an important role due to the possibility of binding antigens for agents such as anthrax, bubonic plague, E. Coli or botulism [83].

Not related with food pathogens or contaminants, but with an important issue in food technology, is the monitoring of specific substances produced during spoilage processes. Fruits and vegetables are the most studied due to the importance of controlling the $\mathrm{O}_{2} / \mathrm{CO}_{2}$ ratio during packaging and storage. It is thus an objective of the industry to have $\mathrm{CO}_{2}$ sensors which could be substantially insensitive to $\mathrm{O}_{2}$ levels, under normal working conditions, and also provide sensors which allows for the combined measurement of $\mathrm{CO}_{2}$ and $\mathrm{O}_{2}$. These kinds of sensors, can inform indirectly about the integrity and hence microbial contamination of packaging, in a non-destructive manner [84]. 
More detailed information about this approach is shown in table 3.

Table 3. Summary of Patents Aimed to develop Food Control Detectors (Approach 2)

\begin{tabular}{|c|c|c|}
\hline $\begin{array}{l}\text { Nano-size } \\
\text { particle }\end{array}$ & Brief Description & Ref \\
\hline \multicolumn{3}{|c|}{$\begin{array}{r}\text { General nano-based sensors } \\
\end{array}$} \\
\hline $\begin{array}{l}\text { Nanoscale } \\
\text { surface }\end{array}$ & $\begin{array}{l}\text { A method for detecting an ingredient in a food product by measuring the } \\
\text { Raman spectrum after the contact of the analyte with a nano-scale surface } \\
\text { structure in the sensor. }\end{array}$ & 85 \\
\hline \multicolumn{3}{|c|}{ Detection of gases produced by food spoilage } \\
\hline $\begin{array}{l}\text { Discotic liquid } \\
\text { crystals }\end{array}$ & $\begin{array}{l}\text { Electronic device with low sensitivity to humidity to detect minute } \\
\text { concentrations of volatile organic compounds. }\end{array}$ & 86 \\
\hline $\begin{array}{l}\text { Nanocrystalline } \\
\text { Zirconinum } \\
\text { dioxide }\end{array}$ & $\begin{array}{l}\text { Method to measure oxygen partial pressure in gases by measuring the } \\
\text { luminescence decay in presence of } \mathrm{O}_{2} \text {. }\end{array}$ & 87 \\
\hline $\begin{array}{l}\text { Surfactant } \\
\text { peptides }\end{array}$ & $\begin{array}{l}\text { Bio-sensing device for odorant detection based on a biologically-derived G- } \\
\text { protein that provides high precision and sensitivity. }\end{array}$ & 88 \\
\hline \multicolumn{3}{|c|}{ Detection of food toxic components or additives } \\
\hline Carbon nanotube & $\begin{array}{l}\text { A biosensor capable of detecting a target substance of glutamate by using a } \\
\text { nanowire that has immobilized a receptor of glutamate. }\end{array}$ & 89 \\
\hline $\begin{array}{l}\text { Carbon nanotubes } \\
+ \text { antigens }\end{array}$ & $\begin{array}{l}\text { Sensor for detecting specific toxic structures of interest in a volume of } \\
\text { atmosphere. }\end{array}$ & 83 \\
\hline Gold nanoparticle & $\begin{array}{l}\text { Device for bio sensing allergens and toxic substances in a solution during } \\
\text { industrial processes. }\end{array}$ & 90 \\
\hline \multicolumn{3}{|c|}{ Detection of foodborne pathogens } \\
\hline $\begin{array}{l}\text { Magnetic } \\
\text { nanoparticles }\end{array}$ & $\begin{array}{l}\text { A novel detection and quantifying method for microorganisms and pathogens, } \\
\text { proteins and antibodies. }\end{array}$ & 91 \\
\hline Quantum dots & $\begin{array}{l}\text { Sensor array capable to recognize a variety of biological molecules including } \\
\text { bacteria, spores, fungi, viruses, and disease-causing prions. }\end{array}$ & 79 \\
\hline Gold nanoparticle & $\begin{array}{l}\text { Method for detecting environmental contaminants and pathogens by means of } \\
\text { using Localized Surface Plasmon Resonance (LSPR) of gold nanoparticles } \\
\text { after an antigen-antibody reaction. }\end{array}$ & 92 \\
\hline
\end{tabular}

\section{CURRENT AND FUTURE DEVELOPMENTS}

There is no doubt that scientists and entrepreneurs have a growing interest in the use of nanotechnology, nanomaterials or nanoprocesses due to its potential to transform the entire food industry by changing the way food is produced, processed, packaged, transported, and consumed. The huge possibilities of nanoscience and nanotechnology in the production of novel food or packaging, enhancing food safety and quality, improving food nutritional value or optimizing food processes is too attractive to pass up. However, this point is not always shared with consumers, who begin to be concerned about the increased exposure and availability of nanofoods, seeing in them a potential health risk and negative environmental consequences. Consequently, the development of nanotechnology applications in food use is slowed since the last 4 years.

The lack of information on the possible toxicity of these materials makes it difficult to assess the safe acceptable daily intake. Thus, special attention should also be given to potential toxicity of nanoparticles depending on their size, shape, chemical composition, surface structure, dosage and exposure routes and regulations of the use of nanotechnology in products intended for human consumption.

To remove the brake on this development, it is therefore necessary to establish clear and specific regulation on the use of nanotechnology in food, in addition to conclusive studies on the adverse effects on health of different families of nanoparticles or nanofoods. Until this comes, generalizations, doubts or 
insecurities will continue to be the main obstacle to the growth of nanotechnology in the food sector, despite its huge possibilities.

\section{ACKOWLEDGEMENTS:}

Financial support from the Spanish Government (project MAT2009-14564-C04-01 and AGL2010-20539) and the Generalitat Valencia (project PROMETEO/2009/016) are gratefully acknowledged. E.P. thanks the Ministerio de Educación for a fellowship

\section{CONFLICT OF INTEREST}

The authors declare no conflict of interest.

\section{REFERENCES}

[1] National Nanotechnology Initiative-NNI (2011). What is Nanotechnology, USA. Available at: http://www.nano.gov/nanotech-101/what/definition. (Accessed on: July 02, 2012)

[2] Silva HD, Cerqueira MA, Vicente AA. Nanoemulsions for Food Applications: Development and Characterization. Food Bioprocess Technol 2012; 5:854-867

[3] Ludlow K, Bowman D, Graeme H. A review of the Possible Impacts of Nanotechnology on Australia's Regulatory Framework. Report to Commonwealth Dept of Industry, Tourism and Resources, August 2007

[4] Fernández A, Cava D, Ocio MJ, Lagarón JM. Perspectives for biocatalysis in food packaging. Trends Food Sci Technol 2009; 19:198-206.

[5] Mozafari MR, Johnson C, Hatziantoniou S, Demetzos C. Nanoliposomes and their applications in food nanotechnology. J Liposome Res 2008; 18:309-327.

[6] Kaya-Celiker H, Mallikarjunan K. Better nutrients and therapeutics delivery in food through nanotechnology. Food Eng Reviews 2012; 4:114-123

[7] Scrinis G, Lyons K. The emerging nano-corporate paradigm: Nanotechnology and the transformation of nature, food and agri-Food Systems. International Journal of Sociology of Agriculture and Food 2007; 15:22-44

[8] Ravichandran R. Nanotechnology applications in food and food processing: Innovative green approaches, opportunities and uncertainties for global market. International Journal of Green Nanotechnology: Physics and Chemistry 2010, 1:72-96

[9] Matin A, Goddard H, Vandermoere F, Blanchemanche S. Do environmental attitudes and food technology neophobia affect perceptions of the benefits of nanotechnology? International journal of consumer studies 2012; 36:149-157

[10] Cushen M, Keery J, Morris M, Cruz-Romero M., Cummins E. Nanotechnologies in the foodindustry - Recent developments, risks and regulation. Trends Food Sci Tech 2012; 24: 30-46

[11] (EC) No 450/2009. Commision Regulation (EC) No 450/2009 of 29 May 2009 on active and intelligent materials and articles intended to come into contact with food. Official Journal of the European Union 2009

[12] Prokisch, J., Zommara, M.A. Process for producing elemental selenium nanospheres. WO2009010922 (2009)

[13] Jeon, J.S., Lee, H.S. Nano-particles containing calcium and method for preparing the same. WO2009011520 (2009)

[14] Hsieh, K.L. Lycopene and resveratrol dietary supplement. WO2010132021 (2010)

[15] Yu, H.G., Ji, H.G., Kim, S.D., Woo, H.K. Nano-emulsion composition of coenzyme $\mathrm{Q}_{10}$. WO2009005215 (2009)

[16] Latva-Nirva, E., Dahms, G., Jung, A., Fiebrig, B. Ultrafine titanium dioxide nanoparticles and dispersions thereof. WO2009141499 (2009)

[17] Livney, Y.D., Dalgleish, D.G. Casein micells for nanoencapsulation of hydrophobic compounds. WO2007122613 (2007) 
[18] Danino, D., Livney, Y.D., Ramon, O., Portnoy, I., Cogan, U. Beta-casein assemblies for enrichment of food and beverages and methods of preparation thereof. WO2009101612 (2009)

[19] Agüero, M., Esparza, I., González, F., González, C.J., Irache, J.M., Romo, A. Nanoparticles for encapsulation of compounds, the production and uses thereof. WO2012007628 (2012)

[20] Livney, Y.D.Beta-lactoglobulin-polysaccharide nanoparticles for hydrophobic bioactive compounds. WO2009130704 (2009)

[21] Oh, D.K., Lee, K.Y. Methods for preparing nanoliposome encapsulation proteins and proteinencapsulated nanoliposome. WO2006109936 (2006)

[22] Sprott, G.D., Patel, G.B.,Makabi-Panzu, B, Tolson, D.L. Archaesomes, archaeosomes containing coenzyme Q10 and other types of liposomes containing coenzyme $\mathrm{Q}_{10}$ adjuvants and as delivery vehicles. US6403117 (2000)

[23] Mannino, R., Krause-Elsmore, S.L., Gould-Fogerite, S. Delmarre, D. Cochleate preparations of fragile nutrients. WO2004064805 (2004)

[24] Tabata, S., Yamada, S., Horie, T., Noguchi, T. Drug sustained release agent, adsorbent, functional food, mask, and adsorptive sheet. EP2324854 (2011)

[25] Ma, Y., Balkus, K.J. Mesoporous compositions for use in drug delivery. US7579014 (2009)

[26] Feher, J. Methods for preparing probiotic nanoparticles. WO2012061629 (2012)

[27] Ismail, A.A., Pinchuk, L., Pinchuk, O.R., Pinchuk, D. Polymer-based antimicrobial agents, methods of making said agents, and products and applications using said agents. WO2008058272 (2008)

[28] Park, C., Kim, Y. Method of providing antibacterial activity on surface of a body using nano-sized metal particles. US0121077 (2004)

[29] Kim, T. Antimicrobial composition containing natural extract, nano silver and natural essential oil. WO2006109898 (2006)

[30] Rai M, Yadav A, Gade A. Silver nanoparticles as a new generation of antimicribials. Biotechnol Adv 2009; 27:76-83

[31] Shin, H., Kang, S. Manufacturing method of antimicrobial fiber using nano silver powder. WO2007032567 (2007)

[32] Yu, H.C., Kim, S.B., Kim, S., OH, M.Y., Kim, Y.H. Bactericidal detergent composition. WO2006071069 (2006)

[33] Zhang, M., Sun, J., Zhao, J., Wang, W., Li, X., Chen, L. An associated sterilization method comprising ozone, ultraviolet and nano-silver coating for quality maintenance of freeze-dried food.WO2009049450 (2009)

[34] Wilson, M., Parkin, I.P., Page, K. A film consisting of a titanium dioxide host matrix comprising silver oxide nanoparticles. WO2007051996 (2007)

[35] Malshe, V.C., Malshe, A.P. Non-metallic nano/micro particles coated with metal, process and applications thereof. WO2007139735 (2007)

[36] Kim J, Grate JW, Wang P. Nanostructures for enzyme stabilization. ChemEngSci 2006; 61:1017-26

[37] Mateo C, Palomo JM, Fernandez-Lorente G, Guisan JM, Fernandez-Lafuente R. Improvement of enzyme activity, stability and selectivity via immobilization techniques. Enzyme Microb Tech 2007; 40:1451-63

[38] Fernandez-Lafuente R. Stabilization of multimeric enzymes: Strategies to prevent subunit dissociation. Enzyme Microb Tech 2009; 45:405-18

[39] ]Betancor L, Luckarift HR. Bioinspired enzyme encapsulation for biocatalysis. TrendsBiotechnol 2008; 26:566-72

[40] Hernandez K, Fernandez-Lafuente R. Control of protein immobilization: Coupling immobilization and site-directed mutagenesis to improve biocatalyst or biosensor performance. Enzyme Microb Tech 2011; 48:107-22

[41] Demirjian D, Moris-Varas F, Gololobov M, Calugaru S. Biocatalysis in chemical processing. Chem Process 1999; 62:57-58.

[42] David, A., Yang, A.: Immobilized enzymes and processes for preparing and using same. WO2007050100 (2007)

[43] Saville, B.A., Khavkine, M.I. Enhancement of enzyme activity through purification and immobilization. WO2004081208 (2004) 
[44] Dinu, C.Z., Dordick, J.S., Kane, R.S., Sanford, K., Whited, G.M., Zhu, G. Enzyme-based nanoscale decontaminating composites. WO2010123534 (2010)

[45] Gu, Y., Cole, B. Carbon nanotube-based glucose sensor. WO2007064355 (2007)

[46] Lu, Y., Zhang, Z., Emanetoglu, N.W., Inoye, M., Mirochnitchenko, O. Multifunctional biosensor based on $\mathrm{ZnO}$ nanostructures. WO2003104789 (2003)

[47] Phadtare, S., Sastry, M. Process for the immobilization of enzymes. US0141596 (2006)

[48] Brody AL. Packaging and the science of tiny. Food Technology 2010; 64:74-6.

[49] Davis, V.A., Simonian, A.L., Nepal, D., Balasubramanian, S. Preparation of precisely controlled thin film nanocomposite of carbon nanotubes and biomaterials. WO2009059023 (2009)

[50] Oksman, K. Nanocomposites based on cellulose whiskers and cellulose plastic introduction. WO2008056989 (2008)

[51] Janssens, M., Daponte, T. Masterbatch composition containing nanoscalar zinc oxide for the production of transparent polyolefin or polyester films with UV-Barrier properties. WO2006003040 (2006)

[52] Wu, W.P., Dobreski, D.V. Polymer films with treated fillers and products and methods of using same. WO2006033983 (2006)

[53] Groendahl, M., Eriksson, L., Gatenholm, P., Hjertberg, T. Polymeric film or coating comprising hemicelluloses. EP2113013 (2009)

[54] Tammaji, K.S., Harish, B. Oxygen scavenging composition. EP1640408 (2006)

[55] Berlin, M., Bentmar, M., Flemmer, K. Method of manufacturing a multi-layer packaging laminate. EP1255615 (2002)

[56] Yener, D.O., Guiselin, O., Bauer, R. Applications of shaped nano alumina hydrate as barrier property enhancer in polymers. US0136744 (2009)

[57] Iyengar, G., Borchardt, T., Lowe, G. Biodegradable and compostable high-barrier packaging material. WO2009005947 (2009)

[58] Johnston, H.J., McFarlane, A.J. Borrmann, Thomas. Nano-structured silicate, functionalized forms thereof, preparation and uses.EP1841692 (2010)

[59] Siegal, D.G., Nelson, K.P. Method that Promotes or Preserves the Desirable Color of Meat EP20090162213 (2009)

[60] Aucejo, S., Jorda, M, Alonso, J.M., Gallur, M., Bermudez, J.M., Hortal, M. B7. Polymer nanocomposite comprising polylactic acid reinforced with the modified phyllosilicate. WO2012017025 (2012)

[61] Lines, R., Schwartz, R.J. Dispersions of nano-sized materials. EP2024448 (2009)

[62] Ebner, C.L., Stockley, W.H. Vacuum packaging of a meat product using a film having a carbon dioxide scavenger. WO2008073220 (2008)

[63] Parker, N.J. A system designed to maintain a predetermined gas composition in modified atmosphere (MA) or controlled atmosphere (CA) packed food, by actively compensating. GB2450860 (2009)

[64] Narayan, R., Balakrishnan, S., Nabar, Y., Raquez, J., Dubois, P. Starch-polyester biodegradable graft copolymers and a method of preparation thereof. WO2006055505 (2006)

[65] Halley, P., Mc Glashan, S., Gralton, J. Biodegradable polymer. WO02083784 (2002)

[66] Netravali, A.N, Huang, X., Lodha, P. Yamamoto, Y. Biodegradable soy protein-based compositions and composites formed therefrom. US20080090939 (2008)

[67] Scheer, F. Biodegradable nano-polymer compositions, i.e. compositions including mineral nanoparticles and poly(lactic acid) polymer and biodegradable articles made thereof. WO2007099427 (2007)

[68] Mencelogly, Y.Z., Inceogluy, F. Biodegradable thermoplastic nanocomposite polymers. US2008033093 (2008)

[69] Sozer N, Kokini JL. Nanotechnology and its applications in the food sector. Trends Biotechnol 2009; 27:82-89.

[70] Pockat, G.R., Schell, T.A., Siegel, D.G., Nelson, K.P., Berbert, O.T. Myoglobin blooming agent containing shrink films, packages and methods for packaging. US07867531 (2011) 
[71] Fayet, P., Rochat, G., Bonnebault, A., Leterrier, Y., Singh, B., Manson, J. Packaging laminate, method for manufacturing of the packaging laminate and packaging container produced there from. WO2008122293 (2008)

[72] Hunt, A.T., Harris, H., Hendrick, M. Antimicrobial coatings. WO2010006036 (2010)

[73] Wagner, T.J., Ziga, M.A. Packaging for extending life of respiring produce and other perishable foodstuffs. WO2009023214 (2009)

[74] Schalkhammer, T. Sensory pigments used on food, packaging, paper and pharmaceutical and electronic products. WO2009029964 (2009)

[75] Dos Santos AC, Ferreira N, Mendes LH, Hespanhol MC, Vieira M, Le Hyaric M, José N, Freitas R, Barbosa A, Gama S. A colorimetric biosensor for the detection of foodborne bacteria. Sensor Actuat BChem 2011; 153:17-23

[76] Vinayaka AC, Thakur MS. Focus on quantum dots as potential fluorescent probes for monitoring food toxicants and foodborne pathogens. Anal Bioanal Chem 2010; 397:1145-1455.

[77] Sinha N, Ma J, Yeow JTW. Carbon Nanotube-Based Sensors. J nanosci nanotechno 2006; 6:573-590 [78] Boussaad, S., Diner, B., Fan, J., Rostovtsev, V. Redox potential mediated carbon nanotubes biosensing in homogeneous format. WO2006137899 (2006)

[79 ] Vinayaka AC, Thakur MS. Focus on quantum dots as potential fluorescent probes for monitoring food toxicants and foodborne pathogens. Anal BioanalChem 2010; 397:1445-1455

[80] Badorrek, C.S., Elrod, D.B., Bowers, M.J., Kim, M., Schull, T.L. Quantum Dot-Sensory array for biological recognition. WO2010141105 (2010)

[81] Lei, Y., Ding, Y. Non-enzymatic glucose sensors based on metal oxide nanomaterials. WO2012018777 (2012).

[82] Ferrao de Paiva, R., Ribeiro, P.M., Correia, E.M. Detection and quantification system of biological matter constituted by one or more optical sensors. EP2059810 (2009)

[83] Henley, D., Anand, A., Imholt, T., Robert, J. Toxic agent sensor and detector method, apparatus, and system. WO2006127884 (2006)

[84] McEvoy, A., MacCraith, B., McDonagh, C., Von-Bultzingslowen, C.: Optical $\mathrm{CO}_{2}$ and combined $\mathrm{O}_{2} / \mathrm{CO}_{2}$ sensors. WO2004077035 (2004)

[85] Wang, H., Guo, X., Liu, C. Systems and methods for food safety detection. US0046284 (2006)

[86] Haick, H. Electronic nose device with low sensitivity to humidity. WO2009053981 (2009)

[87] Lojkowski, W., Millers, D., Fidelus, J., Grigorieva, L., Opalinska, A., Narkiewicz, U., Strek, W.Measurement of oxygen partial pressure based on zirconium dioxide luminescence. EP1920238 (2008) [88] Zhang, S., Mershin, A., Kaiser, L., Cook, B., Graveland-Bikker, J., Prakash, M., Kong, D., Maguire, Y. Bio-sensing nanodevice.WO2009018467 (2009)

[89] Hong, S., Lee, B.; Lee, D. Biosensor having nano wire for detecting food additive mono sodium glutamate and manufacturing method thereof. WO2007114650 (2007)

[90] Olofsson, L., Hansson, N., Olofsson, N., Lundgren, A., Nordberg, P. Sensor for detection of single molecules. WO2006088425 (2006)

[91] Stroemberg, M., Goeransson, J., Gunnarsson, K., Nilsson, M., Svedlindh, P., Stroemme, M. Magnetic detection of small entities. WO2009037659 (2009)

[92] Sim, SJ., Kim, J.P., Cao, C. Method of detecting bioproducts using localized surface plasmon resonance sensor of gold nanoparticles. WO2009102092 (2009) 